TITLE:

\title{
Serial analysis of gene expression in a microglial cell line(Abstract_要旨 )
}

$\operatorname{AUTHOR}(S)$ :

Inoue, Haruhisa

CITATION:

Inoue, Haruhisa. Serial analysis of gene expression in a microglial cell line. 京都大学, 2000, 博士(医学)

ISSUE DATE:

2000-11-24

URL:

http://hdl.handle.net/2433/151444

RIGHT: 


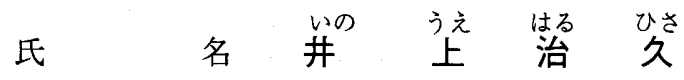

学位(専攻分野) 博士（医学）

学位記番号論医博第 1726 号

学位授与の日付平成 12 年 11 月 24 日

学位授与の要件 学位 規則第 4 条第 2 項該 当

学位論文題目 Serial analysis of gene expression in a microglial cell line

(小神経膠細胞細胞株における遺伝子発現の連続的解析)

論文調査委員 教授橋本信夫教授井出千束教授柴崎浩

論文内容 の 要旨

（目的）ミクログリア（小神経膠細胞）は1932年に高名な解剖学者 Hortegaにより存在が確認された。中枢神経系細胞 の 5 20\%を構成するといわれている。ミクログリアは脳の免疫担当細胞として, 各種の神経栄養因子やその他のサイトカ イン産生細胞として, また異物のスカベンジャーとして, 生理的抢よび病的状熊に扔いて極めて重要な働きをしている。ま た, ミクログリアは, 表面マーカーや䕘食能, 細胞内醘素などではマクロファージと殆ど区別がつかないが, 最近, マクロ ファージと異なり，脳に対して高い親和性を有するという知見が得られている。

本研究はミクログリアで発現している遺伝子を serial analysis of gene expression（SAGE）法により解析することによ り，各種の病態に関与し，また脳に高い親和性を有するミクログリアの分子的基盤を明らかにすることを目的とした。

(方法) SAGE 法による解析にはミクログリア細胞株Ra 2 を用いた。Ra２は新生 B 6 マウス脳より分離したミクログリア をリコンビナント mGM-CSF で培養維持し不死化したものである。この細胞は, GM-CSF 非存在下では增殖を停止し， 生体に戻した時には腫愓性を発揮しない特徴がある。得られた遺伝子の発現を確認するために新生マウス脳より常法により 分離したミクログリア（純度99\%以上）を用いてRT-PCR を行った。

(結果) Ra 2 細胞株より分離した mRNA から 10,386個の sequence tag を得た。それらは6,013種類あり，そのうち1,324 個はマウスその他の種に扔いて既知の遺伝子として登録されていた。遺伝子発現頻度は 1 回から 243 回であった。ferritin light chain (243回), heat shock protein 70 cognate (61回), ECF-L precursor（61回）等が特に高頻度にみられた。これ までにミクログリアに発現が確認されている免疫関連遺伝子として，C10，IL-18, TGF- $\beta$, MMRP 2 ，表面分子として $\beta 2$-microglobulin, CD18 $\beta, \mathrm{CD} 36$ などが高頻度にみられた。免疫関連遺伝子でこれまでミクログリアでの発現が報告されて いないものとして, EMAP I, CD107a, laminin 受容体などが高頻度であった。ミクログリアの起源を示唆する遺伝子とし $\tau$, retinoic acid-inducible E3 protein, hematopoietic-specific early response protein, hematopoietic-specific protein 1, EN-7, ufo, Hn 1, primary response gene B94などが見い出された。一部の遺伝子については一次培養ミクログリアでの 発現を確認した。(結論) 本研究により, ミクログリアでの発現が報告されていない免疫関連遺伝子が遺伝子発現プロファ イル中に見い出された。中には細胞接着に関連するものもあり，既知の接着分子とともにこれらが脳への高親和性に関連し ている可能性がある。ミクログリアの発生起源については諸説があるが，本実験の遺伝子発現プロファイルには造血系ある いは中胚葉性細胞特異的遺伝子が複数個含まれ，中でもHn 1 は10日胚 yalk sac の血島赤芽球に発現し，その後，造血系細 胞と神経系細胞に発現がみられることから，ミクログリアの脳へのホーミングが発生初期に生じていることの分子的裹付け であると考えられた。

\section{論文審査の結果の要旨}

ミクログリアは，脳の免疫担当細胞として，各種の栄盖因子やサイトカイン産生細胞として，また異物のスカベンジャー として, 生理的および病的状態において極めて重要な働きをしている。しかし, 依然として, その機能や起源については未 
知の部分が多い。本研究では，ミクログリア細胞株 Ra 2 の total RNA を材料に, serial analysis of gene expression （SAGE）を用いて，ミクログリアの発現遺伝子の解析を行なった。一部の遺伝子については，初代培養ミクログリアでの 発現を確認した。その結果, 免疫関連遺伝子でこれまでミクログリアでの発現が報告されていないものとして, EMAP I, CD107a, laminin 受容体などの発現が高頻度であった。ミクログリアの起源を示唆する遺伝子として, retinoic acid-inducible E3 protein, hematopoietic-specific early response protein, EN-7, ufo, Hn 1, B94などの中胚葉特異的遺伝 子や造血系特異的遺伝子が見出された。

以上の研究は，ミクログリアの分子的基盤の解明に寄与するところが大きい。したがって，本論文は博士 (医学) の学位 論文として価値あるものと認める。

なお，本学位授与申請者は，平成12年10月16日実施の論文内容とそれに関連した試問を受け，合格と認められたものであ る。 